\title{
A new Antarctic Peninsula glacier basin inventory and observed area changes since the 1940s
}

\author{
A.J. COOK ${ }^{1}$, D.G. VAUGHAN ${ }^{2}$, A.J. LUCKMAN ${ }^{1}$ and T. MURRAY ${ }^{1}$ \\ ${ }^{1}$ Department of Geography, Swansea University, Swansea SA2 8PP, UK \\ ${ }^{2}$ British Antarctic Survey, NERC, High Cross, Madingley Road, Cambridge CB3 OET, UK \\ 577453@swansea.ac.uk
}

\begin{abstract}
Glaciers on the Antarctic Peninsula have recently shown changes in extent, velocity and thickness, yet there is little quantification of change in the mass balance of individual glaciers or the processes controlling changes in extent. Here a high-resolution digital elevation model and a semi-automated drainage basin delineation method have been used to define glacier systems between $63^{\circ} \mathrm{S}-70^{\circ} \mathrm{S}$ on the mainland and surrounding islands, resulting in an inventory of 1590 glacier basins. Of these, 860 are marine-terminating glaciers whose ice fronts can be defined at specific epochs since the 1940s. These ice front positions were digitized up to 2010 and the areas for all individual glacier basins were calculated. Glaciological characteristics, such as geometry, slope and altitudes, were attributed to each glacier, thus providing a new resource for glacier morphological analyses. Our results indicate that $90 \%$ of the 860 glaciers have reduced in area since the earliest recorded date. A north-south gradient of increasing ice loss is clear, as is distinct behaviour on the east and west coasts. The area lost varies considerably between glacier types, with correlations apparent with glacier shape, slope and frontal-type. Temporal trends indicate a uniform retreat since the 1970s, with a period of small re-advance in the late 1990s.
\end{abstract}

Received 3 September 2013, accepted 13 March 2014

Key words: glacier basin outlines, glacier characteristics, frontal change

\section{Introduction}

Glaciers throughout the Antarctic Peninsula (AP) have undergone extensive change in recent decades (Cook et al. 2005, Pritchard \& Vaughan 2007, Pritchard et al. 2009, Kunz et al. 2012) and are subject to rapid climate warming from both the atmosphere and ocean (Barrand et al. 2013a). There is extensive evidence that since the 1950s there have been significant changes in the climate on the AP such as an increase in air temperature (Vaughan et al. 2003, Steig et al. 2009, Mulvaney et al. 2012), near-surface warming in the seas to the west (Meredith \& King 2005), a corresponding reduction in sea ice extent (Smith \& Stammerjohn 2001), and an increase in precipitation and snow accumulation (Turner et al. 2005, Thomas et al. 2008). Estimations of ice mass change suggest that glaciers in this region are particularly sensitive (Hock et al. 2009), and an accelerated mass loss has occurred during recent years (Chen et al. 2009, Ivins et al. 2011). Within the entire AP glacier system there are numerous individual regional and local ice masses. Outlet glaciers drain to the east and west from the plateau of the AP ice sheet, and ice caps, mountain glaciers and piedmonts are prevalent along the margins and adjacent islands. These relatively small ice masses are crucial indicators of the variability of the regional climate system; by measuring their characteristics we can begin to understand the response both locally and across the system as a whole.

A prerequisite for continued glacier-by-glacier mass balance studies is the definition of outlines for each individual ice mass. A recent inventory was produced for outlines of mountain glaciers and ice caps around the periphery of Antarctica, which includes glaciers on the offshore islands surrounding the AP (Bliss et al. 2013) and other glacier delineations exist for specific regions within the AP (Rabassa et al. 1982, Braun et al. 2001, Rau et al. 2004, Davies et al. 2012). However, a comprehensive inventory, using a consistent technique, is necessary to incorporate all glacier systems on both the mainland and surrounding islands.

Since the AP is almost entirely covered in ice, distinguishing between glaciers and the ice sheet is not straightforward (Rau et al. 2006, Bliss et al. 2013) and definitions may vary depending on the intended usage. Many glacier inventories for non-Polar regions have been produced using semi-automated multispectral glacier mapping methods (e.g. Paul et al. 2002, Bolch et al. 2010). However, these methods cannot be easily applied in the AP region due to year-round snow and firn cover in most regions and the multi-part glaciology of the ice sheet. Mapping the drainage basin boundary as an 

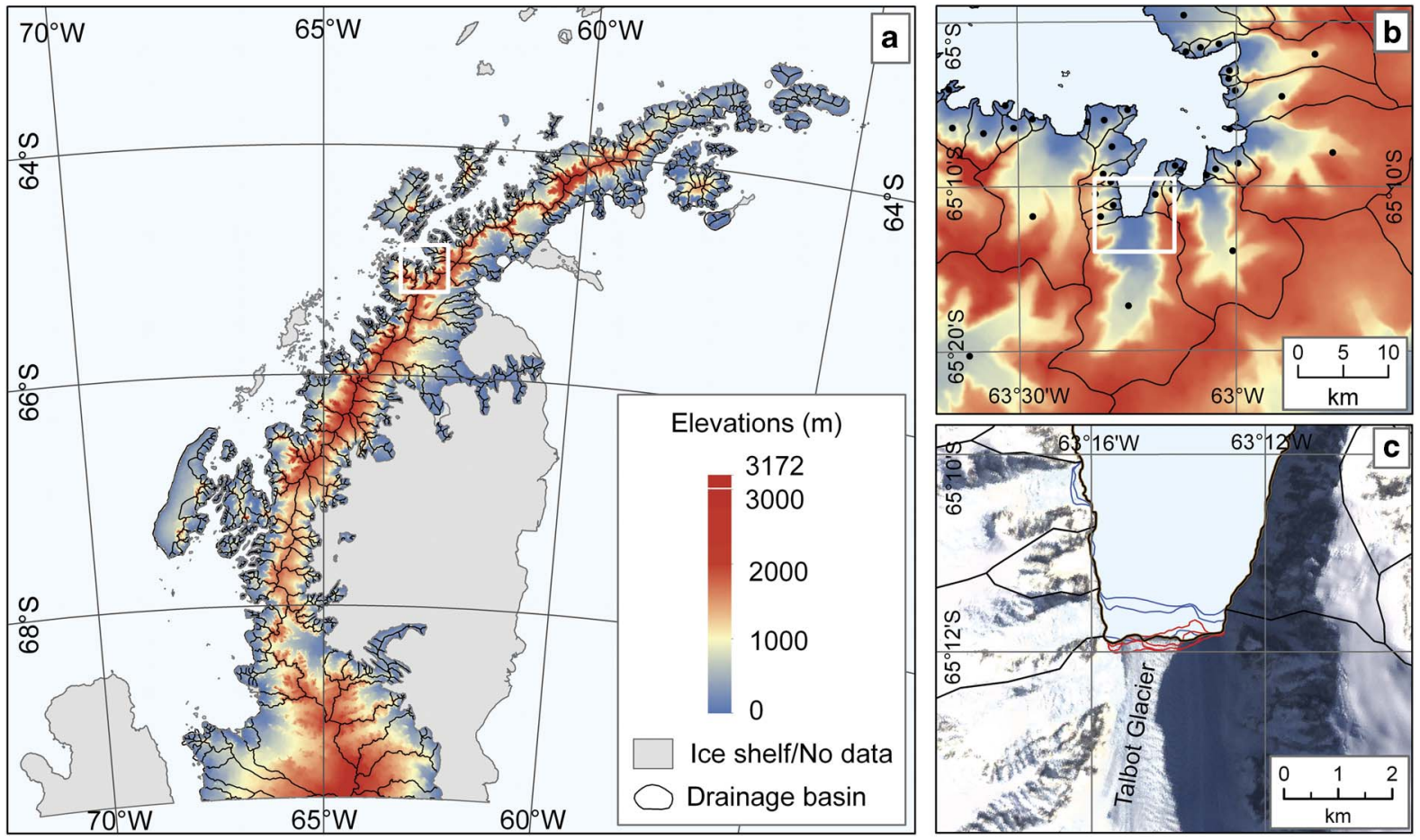

Fig. 1. Glacier drainage basin outlines. a. Shows the spatial extent of the glacier outlines. The white box is the inset shown on b. which illustrates the level of detail of the dataset. The white box on b. indicates the larger scale plot shown in $\mathbf{c}$. which is a sample glacier showing the ice-front data; red lines are post-2000 ice fronts and blue lines are pre-2000. The background image is Landsat ETM+ image LE7218106000105250, 21/02/2001.

alternative to the ice-rock interface is a practical solution for defining individual glacier flow units. Where glaciers are connected (e.g. an outlet draining an ice cap), the ice divide is used as the basin limit. Since snow and exposed rock may be included within the boundaries, they are basins rather than glacier outlines, but each basin has only one glacier terminus.

One significant factor preventing the mapping of glacier boundaries is that there has been no topographic model of sufficient resolution or accuracy to capture the steep-sided coastal regions and relatively small glaciers that are prevalent on the AP. In this paper, we describe how a new 100-m resolution digital elevation model (DEM) (Cook et al. 2012), combined with a semi-automated drainage basin delineation approach, has ensured a consistent identification of boundaries, resulting in a new inventory of glacier drainage basin outlines that can provide a resource for future mass balance studies. We use these boundary outlines alongside the existing coastalchange and glaciological maps of Antarctica dataset of historical ice front positions (Williams et al. 1995, Cook et al. 2005, Ferrigno et al. 2006, 2008, 2009) and, as a result, increase the number of marine-terminating glaciers for which a record of frontal change can be defined from 244 (Cook et al. 2005) to 860 glaciers. This new dataset allows area measurements to be made, improving the possibilities for interpreting glacier changes in this region. We calculate the area changes for all 860 glaciers, from records as early as 1945 to 2010, and discuss correlations between glacier characteristics and spatio-temporal patterns of change.

\section{Methods}

\section{Glacier basin delineation}

The AP differs from the rest of the Antarctic continental ice sheet; it is a narrow mountainous chain bounded to the east and west by ocean and has a distinctive climatic regime. The topography consists of numerous steep and heavily-crevassed mountain glaciers, in contrast to the large, low-sloping ice streams making up most of the continental fringe. Along the west coast, the glaciers between Trinity Peninsula in the north $\left(63^{\circ} \mathrm{S}\right)$ and George VI Sound in the south $\left(70^{\circ} \mathrm{S}\right)$ are almost all marineterminating; further south the glaciers flow into ice shelves. Along the east coast, the glaciers north of $66^{\circ} \mathrm{S}$ are primarily marine-terminating and further south they feed the Larsen Ice Shelf. The primary focus for glacier change is the marine-terminating glaciers, thus the boundary used was $63^{\circ} \mathrm{S}-70^{\circ} \mathrm{S}$ and $55^{\circ} \mathrm{W}-70^{\circ} \mathrm{W}$. The area of this region (including islands and excluding ice shelves) is $c .98000 \mathrm{~km}^{2}$, which is $c .0 .7 \%$ of the area of the continent, and more than $96 \%$ of this area is ice-covered. 
Table I. Primary classifications (Class) and frontal characteristics (Front) of 1590 glacier basins on the mainland and islands surrounding the Antarctic Peninsula.

\begin{tabular}{|c|c|c|c|c|c|c|c|}
\hline & & Mainland & Island & Total count & Total count $\%$ & Sum area $\left(\mathrm{km}^{2}\right)$ & Sum area $(\%)$ \\
\hline \multirow{4}{*}{ Class } & Ice field & 72 & 5 & 77 & 5 & 3410 & 4 \\
\hline & Ice cap & 98 & 136 & 234 & 15 & 12798 & 13 \\
\hline & Mountain glacier & 358 & 193 & 551 & 35 & 8636 & 9 \\
\hline & Small island & & 101 & 103 & 6 & 455 & 0 \\
\hline \multirow[t]{6}{*}{ Front } & Uncertain/miscellaneous & 193 & 251 & 444 & 28 & 2124 & 2 \\
\hline & Calving/lobed & 13 & 28 & 41 & 3 & 4560 & 5 \\
\hline & Ice-shelf nourishing & 250 & 14 & 264 & 17 & 33739 & 35 \\
\hline & Floating & 74 & 8 & 82 & 5 & 24593 & 25 \\
\hline & Land-terminating & 0 & 9 & 9 & 1 & 171 & 0 \\
\hline & Total & 971 & 619 & 1590 & & 96982 & \\
\hline
\end{tabular}

A topographic model can provide the information required for glacier basin delineations if the resolution is sufficient for the scale of the features. A recently derived 100-m resolution DEM, created by improving the ASTER Global DEM in the AP region (Cook et al. 2012), is used here as the basis for the basin delineations. With a mean elevation accuracy of $4 \mathrm{~m}( \pm 25 \mathrm{~m}$ root mean square error), this is regarded as suitable for watershed delineation of both small, steep-sided glaciers and those originating on the gentler relief of the plateau. In order to minimize subjectivity, hydrological tools available in a geographic information system (GIS) package were used to automate delineation of glacier drainage basins. Normally such tools require a 'pour point' on the coast where the river exits the catchment and the algorithm calculates the distance upstream until it reaches the watershed. Instead of using a point outlet, a line denoting the glacier ice front was defined, which forces the algorithm to include the whole surrounding glacier catchment. This method is similar to that employed by Bliss et al. (2013).

The AP coast line was digitized based on the Landsat Image Mosaic of Antarctica (LIMA) (Bindschadler et al. 2008), which consists of Landsat scenes from between 2000 and 2002. Therefore, the basins are all based on a consistent time period. In the case of the Larsen Ice Shelf, which in 2002 covered the entire east coast of the AP south of $65.5^{\circ} \mathrm{S}$, the grounding line was used to divide the drainage basins. This was primarily based on the Antarctic Surface Accumulation and Ice Discharge (ASAID) project data source (Bindschadler et al. 2011), modified in places with features visible on the LIMA. As the delineation algorithm only works within the boundary of the DEM, the lines have been clipped to the extent of the ASTER 100-m DEM, which is missing some small sections at the coast/grounding line $(2.1 \%$ of the total area).

The watershed was determined by the positions of the side boundaries at the glacier front. These were produced by clipping the line at the mouth of each glacier, based on visual interpretation from LIMA, slope changes visible in the DEM and changes in ice velocity visible on an ice flow mosaic (Rignot et al. 2011). In many cases separate glacier entities coalesce to form a single glacier at the terminus, in which case the resulting basin is termed 'compound'. After the creation of the watershed boundary polygons, manual correction of small artefacts was necessary in some cases. Sections of rock coast, islands that are predominantly ice-free and basins $<0.5 \mathrm{~km}^{2}$ are not included in the database. The result is a total of 1590 glacier outlines with area, date and source details (Fig. 1a \& b) (available for download from the ADD, http://add.scar.org/).

\section{Glacier attributes}

Further attributes were assigned in accordance with the Global Land Ice Measurements from Space (GLIMS) inventory specifications (Rau et al. 2005). Glaciers are not sub-divided into as many glacial units as in the World Glacier Inventory (WGI), and the attributes apply to the drainage basins and not the individual glacier entities within the basins. Attributes include a primary classification (Class), basin shape (Form) and frontal-type (Front), as defined for the GLIMS inventory (e.g. see Table I). Furthermore, an overall confidence rating regarding decisions about these classifications was established. The grounding line is not clearly identifiable for many marine-terminating glaciers thus the term 'floating' was only assigned in cases where it was considered to be unambiguous. These decisions were based on the positions of the ASAID grounding line, combined with interpretation from features visible on the LIMA. No measurements were made using the grounding line and, therefore, its position does not affect the results, with the exception of defining floating glaciers. An additional Class type was added to denote 
Table II. Distribution of ice-front records per glacier basin.

\begin{tabular}{|c|c|c|c|c|c|c|c|c|c|c|c|}
\hline & \multicolumn{10}{|c|}{ Number of records per glacier } & \multirow[t]{2}{*}{ All records } \\
\hline & 2 & 3 & 4 & 5 & 6 & 7 & 8 & 9 & 10 & 11 & \\
\hline Number of basins & 56 & 122 & 214 & 157 & 105 & 108 & 62 & 21 & 12 & 3 & 860 \\
\hline Total records & 112 & 366 & 856 & 785 & 630 & 756 & 496 & 189 & 120 & 33 & 4343 \\
\hline Mean first year & 1984 & 1967 & 1959 & 1955 & 1955 & 1953 & 1949 & 1949 & 1948 & 1947 & 1958 \\
\hline Mean last year & 2002 & 2002 & 2001 & 2002 & 2005 & 2007 & 2008 & 2009 & 2009 & 2009 & 2004 \\
\hline
\end{tabular}

a small ice-covered island (1-5 km long/wide) as such features are prevalent along the west coast. The term 'uncertain/miscellaneous' is used where a coastal region is ice-covered but does not match a distinct glacier-type, although the term 'ice wall' has been used to describe this widespread feature in Antarctica (Williams et al. 1995).

Geometric and descriptive characteristics were assigned to the marine-terminating glaciers, such as glacier name, area, length, outlet width, shape, altitude distribution, slope and aspect. Glacier basin areas were calculated on a Lambert azimuthal equal area projection whose origin is at the South Pole and central meridian is at $65^{\circ} \mathrm{W}$. Due to the complex nature of many of the glaciers, defining a single measure of glacier basin length was not straightforward. For example, many catchments contain more than one glacier flowing towards a single terminus, which means that the length of a straight centreline through the basin can give a very different result from the lengths of the main branch or tributaries within the basin. A GIS algorithm was used to derive centrelines based on a 'least-cost route approach' between the glacier head and terminus, in which branch orders were allocated (Kienholz et al. 2014). This file was manually edited resulting in a line for every glacier basin that best represents the central flow line of the main glacier branch.

Glacier front widths were based on the straight line distance between the two end points defining the glacier front, and mean basin widths were calculated by dividing the glacier basin area by its centreline length. Such geometric quantities can be used to characterize the basin shape, for example, the degree of convergence. If the width of the front is less than the mean width, the glacier is classified as convergent, while a glacier with an outlet width greater than the mean width is classified as divergent. Threedimensional glacier geometry characteristics included in the attributes are maximum, minimum, and mean elevation and slope, calculated from DEM pixel values along the centreline. Although this is biased (since only centre values are considered), it is a more robust representation of the glacier surface than if values for the whole basin are used, as it omits the ice-free, steep-sided valley walls.

\section{Glacier change data}

Positions of glacier fronts on the AP can be identified from many archival forms, such as aerial photographs, maps and satellite images. A comprehensive inventory using all records up to 2002 was compiled as part of the United States Geological Survey (USGS) coastal-change and glaciological maps of Antarctica project (Williams et al. 1995). The results were published as maps and information booklets (Ferrigno et al. 2006, 2008, 2009) and used in an analysis of changes in glacier length based on 244 glaciers (Cook et al. 2005). The new dataset of glacier basin outlines enables the coastal-change data to be analysed more fully since the historic ice fronts can now be associated with corresponding glacier basin outlines, and calculations of changes in glacier extent can be based on area rather than length.

Glacier fronts in the coastal-change inventory were joined to the relevant basin outlines to create a closed polygon for every data record. In addition, since the original dataset used the Institut für Angewendt Geodesie (IfAG) mosaic as a base image, all coastlines needed to be updated and georegistered to the more geospatially accurate LIMA mosaic. As image georegistering between the two mosaics introduced considerable errors, this was done on a glacier-by-glacier basis, where neighbouring stationary features (e.g. rock promontories) digitized from the IfAG mosaic, were used to align the coastline data to the same features visible on the LIMA mosaic. Finally, the data were updated by manually digitizing more recent ice front positions to fill gaps since 2002 up to 2010, primarily using Landsat ETM+ satellite imagery and, where these were missing/cloud-covered, European Remote Sensing satellite-2 (ERS-2) synthetic aperture radar imagery. A description of source material and digitization methodology can be found in the original coastal-change documents (Ferrigno et al. 2006, 2008, 2009). The result is a new GIS database of 4343 glacier basin measurements presented as polygons, where each polygon contains associated attributes (Table II shows the distribution of ice-front records per basin and a sample of the ice fronts are shown in Fig. 1c).

A challenge when measuring changes in marine ice fronts is that they can change between floating and grounded, and can also either merge with or separate from neighbouring ice fronts. In the new dataset, many glacier basins that were once merged with other basins are now separate entities because they have receded past a point of convergence. As this is primarily a study of changes in glacier drainage basins two clarifications need to be made to our approach. Firstly, the basin outlines are 


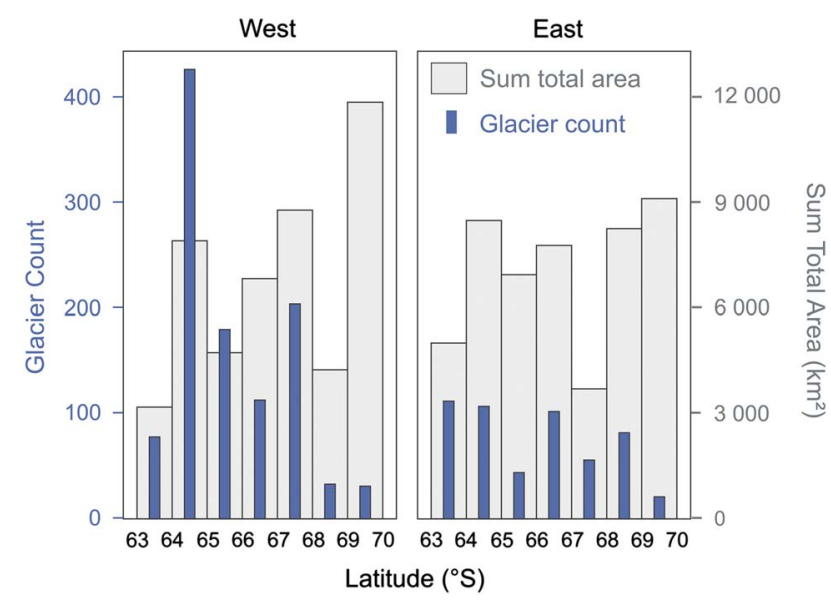

Fig. 2. Number and area coverage of all glacier systems divided by east/west and degree latitude. The definition of an east/west glacier is determined by the location of its terminus.

based on the ice-front position as it appears on the LIMA (2000-02), regardless of the position of the grounding line. If any basins in 2000-02 were once part of larger basins, we group them according to the maximum extent of the basins when they were merged, to a limit of five basins. Secondly, some basins in 2000-02 contained glaciers that coalesced downstream of the grounding line (termed ice shelves). They may have since receded and separated into basins with single glacier fronts. In these cases the five basin limit is based on the most recent frontal positions. Accordingly, measurements of glacier basins adjoining the Larsen A, Larsen B and Wordie ice shelves only begin after the major episodes of ice shelf collapse.

For area-change analysis, small ice-covered islands, ice walls, ice-shelf nourishing or land-terminating glaciers were removed from the dataset of 1590 basin outlines. From these 925 marine-terminating glaciers, those with an area $<1 \mathrm{~km}^{2}$ or with only one frontal position record were also excluded $(n=28)$. Following this, multiple basins that were once one entity were merged (as described above), resulting in a total of 860 glacier basins with two or more ice-front position records. The areas of all ice-front record polygons associated with each glacier basin were then calculated and assigned to this new dataset. Glacier change attributes calculated for each glacier basin include: overall area change, area change relative to glacier size, data record details and glacier area (in $\mathrm{km}^{2}$ and $\%$ ) at each available time period.

\section{Uncertainties}

The largest sources of uncertainty in measuring glacier change include the reliability of source material, measurement error and methods used to calculate change. The large number of data sources, each having

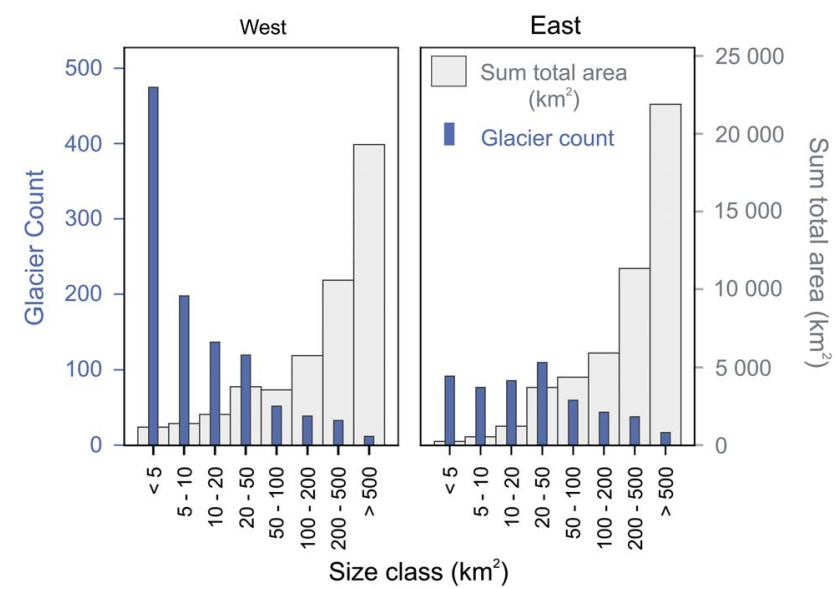

Fig. 3. Number and area coverage of all glacier systems divided by east/west and size class.

different characteristics, spatial resolutions and geodetic accuracies, necessitated an accuracy assessment unique to the AP. A method was developed for the coastal-change study (Ferrigno et al. 2006), where reliability ratings were assigned to every data source. This same approach was applied to all data sources in this study and the results show that the majority $(68 \%)$ of the records have a reliability rating of 1 (estimated to be accurate to within $60 \mathrm{~m}$ in length, equivalent to $\left.0.0036 \mathrm{~km}^{2}\right), 25 \%$ have a rating of 2 (within $150 \mathrm{~m}$ or $0.0225 \mathrm{~km}^{2}$ ) and $7 \%$ have a rating of 3 (within $300 \mathrm{~m}$ or $0.09 \mathrm{~km}^{2}$ ). Glacier fronts with a rating of 3 are generally derived from vertical or oblique aerial photographs in which few or no reference features are visible, or from satellite images or large-scale maps which are poorly georeferenced but still show useful coastline data. The ratings take into account manual digitization and interpretation errors, which were measured using stationary features as a guide. A more detailed description of coastline accuracies can be found in Ferrigno et al. (2006).

Unlike measurements of changes in glacier length, glacier area measurements take into account uneven changes along the ice front and offer a more precise assessment of change than can be obtained using alongflow sample-lines. Differencing of polygon areas from one epoch to another can provide values of absolute area change, as well as change relative to basin size.

\section{Glacier distribution and characteristics}

Our analysis shows that the total area of the AP in the period $2000-02$ between $63^{\circ} \mathrm{S}-70^{\circ} \mathrm{S}$ was $98293 \mathrm{~km}^{2}$ (inclusive of exposed rock and small islands but excluding ice shelves). When small $\left(<0.5 \mathrm{~km}^{2}\right)$ islands and drainage basins that are predominantly ice-free are excluded, a total of $96982 \mathrm{~km}^{2}(98.7 \%)$ in 1590 glacier drainage basins remain. By further excluding an approximate area 


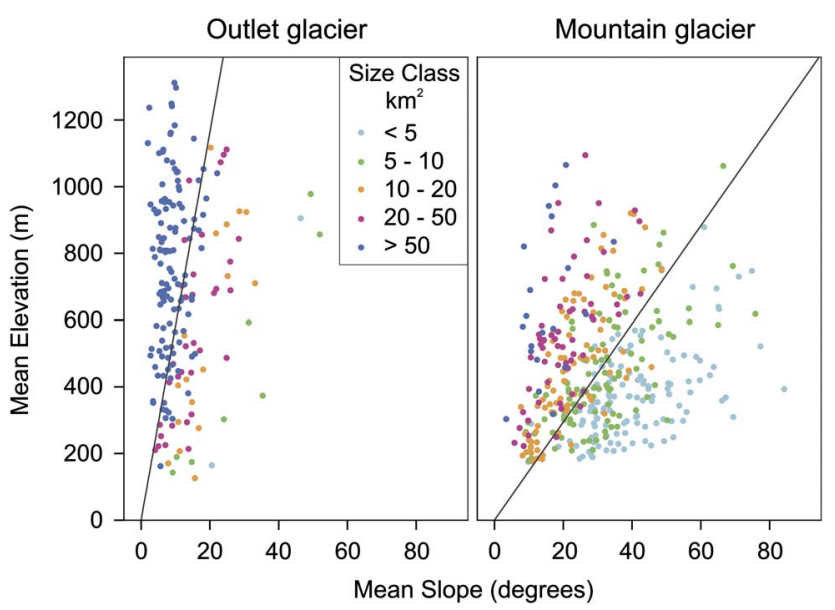

Fig. 4. Elevations and slopes grouped by glacier size class, for outlet and mountain glaciers.

representing exposed rock (obtained from the ADD), the estimated ice-covered area for this region is $94646 \mathrm{~km}^{2}$ (96.3\%). To best facilitate spatial analysis, the AP was divided into two distinct eastern and western sides and into the seven one-degree latitudinal bands that cross the $1000 \mathrm{~km}$ long peninsula.

The spatial distribution of glaciers and total icecovered area is shown in Fig. 2. The number of glaciers is latitudinally more evenly distributed along the eastern side than along the western side. From the total of 1590 glaciers, by far the largest number $(n=427)$ occur in the west between $64^{\circ} \mathrm{S}-65^{\circ} \mathrm{S}$, whereas only 31 glaciers are found within the western band $69^{\circ} \mathrm{S}-70^{\circ} \mathrm{S}$. However, the total glaciated area in this section is by far the largest and it contains the largest glacier basin on the peninsula, Fleming Glacier $\left(7021 \mathrm{~km}^{2}\right)$.

The western region has a strong negative relationship between the size class and number of glaciers, and an opposing similarly strong positive relationship with the sum total area (Fig. 3). The former relationship is not as pronounced in the east, where there are fewer glaciers in the smaller size categories. In total, $36 \%(n=567)$ of glaciers are $<5 \mathrm{~km}^{2}$ but altogether these cover $<1.5 \%$ $\left(1432 \mathrm{~km}^{2}\right)$ of the total glaciated area, whereas the 29 glaciers $>500 \mathrm{~km}^{2}(1.8 \%$ of all glaciers $)$ cover $42.5 \%$ $\left(41246 \mathrm{~km}^{2}\right)$ of the total area. Further descriptions of glacier types are shown in Table I, where the number of glaciers within each classification and frontal-type is listed. The largest population of glaciers $(35 \%)$ are the mountain glaciers, which occur in similar proportions on both the mainland and islands. Glacier types that differ significantly between the mainland and islands are outlet glaciers ( $85 \%$ on the mainland) and ice fields ( $94 \%$ on the mainland). As regards frontal type, the highest percentage $(42 \%)$ are in the 'calving' category. A rather large proportion (28\%) was assigned 'uncertain/ miscellaneous' as the grounding line is unclear in many
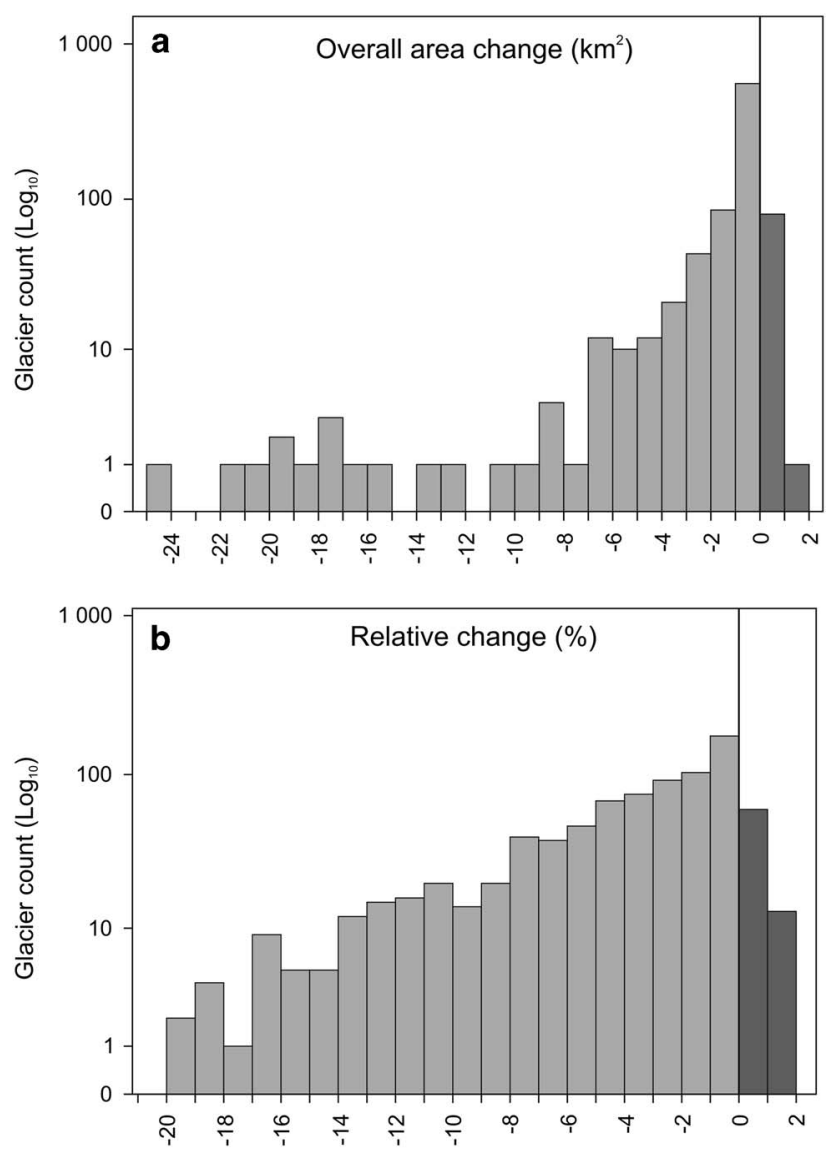

Fig. 5. a. Overall change per glacier $\left(\mathrm{km}^{2}\right)$ and b. relative change per glacier ( $\%$ of basin size) from earliest to latest records. Records are variable for each glacier but earliest positions are, on average, 1958 and latest positions are, on average, 2004 (weighted by basin area these are 1968 and 2007, respectively). Due to the large negative dispersion range, data from the extremes $(<0.02$ and $>0.98)$ have been excluded.

cases, and many of these could be floating. There were only nine glaciers that could be described as 'landterminating' during the period $2000-02$, and all of these occur on James Ross Island.

The dataset lends itself to the characterization and comparison of glaciers in many ways, including those based on surface elevation details. Mean elevations and slopes of different glacier categories and size classes highlight differences between glacier types in this region (Fig. 4). Mean elevation and slope of mountain glaciers are very dependent on glacier area, for example, small glaciers tend to have low mean elevations and high mean slope angles. Large outlet glaciers tend to have low mean slope angles irrespective of the mean elevation.

\section{Glacier changes}

Reinforcing the result of an earlier study of 244 glaciers (Cook et al. 2005), our study of 860 marine-terminating 

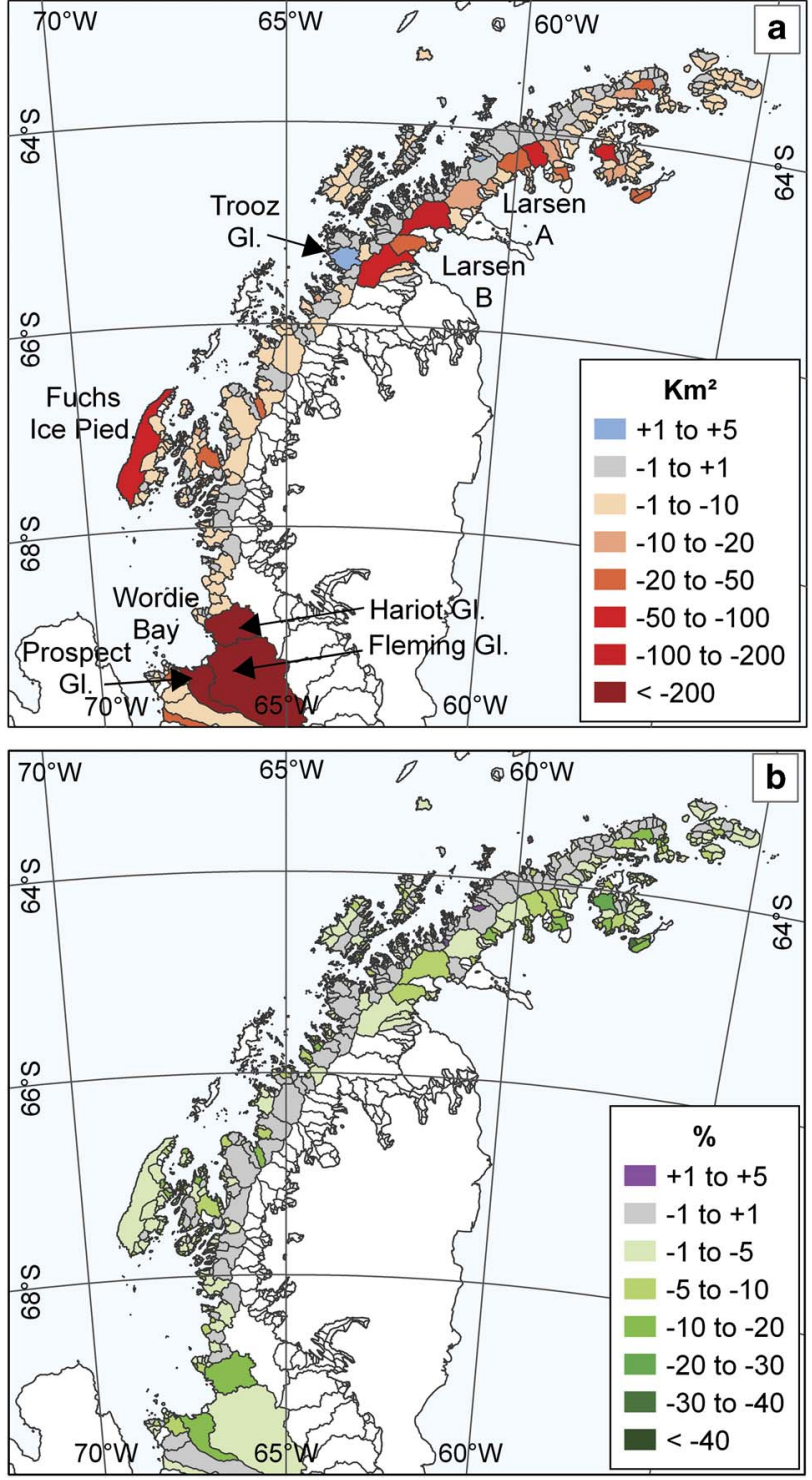

Fig. 6. Spatial distributions of overall change in area from earliest to latest records. a. Overall change in $\mathrm{km}^{2}$ and b. overall change as \% of basin size. Earliest recorded positions are, on average, 1958 and latest positions are, on average, 2004.

glaciers on the peninsula shows that $90.5 \%$ have retreated since the earliest recorded ice-front position (average 1958). In total, 30 (3.5\%) glaciers lost $>10 \mathrm{~km}^{2}, 190(22 \%)$ glaciers lost between $1-10 \mathrm{~km}^{2}$ and the majority $(n=558$, $65 \%$ ) showed minimal retreat $\left(<1 \mathrm{~km}^{2}\right)$. Of the $82(9.5 \%)$ that advanced, 80 of these changed by $<1 \mathrm{~km}^{2}$ (Fig. 5a).
When area change is calculated relative to the basin size, the distribution is also negatively skewed but with a greater dispersion around the mean (Fig. 5b). This can be explained by the diverse range of glacier sizes; there are many small glaciers that may show only a small absolute area change but a large relative change.

The spatial distribution of overall change (Fig. 6a) shows that the largest area loss has occurred to glaciers flowing into Wordie Bay, where Fleming Glacier (consisting of Fleming, Airy and Seller glaciers) lost $329 \mathrm{~km}^{2}$ between 1997 and 2010, following collapse of the Wordie Ice Shelf. The two large neighbouring glaciers (Hariot and Prospect glaciers) lost $251 \mathrm{~km}^{2}$ and $204 \mathrm{~km}^{2}$, respectively. Large losses also occurred to glaciers such as Hektoria $\left(113 \mathrm{~km}^{2}\right)$, Crane $\left(50 \mathrm{~km}^{2}\right)$ and Jorum $\left(43 \mathrm{~km}^{2}\right)$ which once flowed into the Larsen B Ice Shelf, and Pyke $\left(56 \mathrm{~km}^{2}\right)$ and Edgeworth $\left(32 \mathrm{~km}^{2}\right)$ glaciers which once fed the Larsen A Ice Shelf to the north. These results correspond with studies that have shown mass deficit due to tributary glacier acceleration and thinning post-ice shelf collapse (Scambos et al. 2004, Rignot et al. 2005, Wendt et al. 2010, Rott et al. 2011, Shuman et al. 2011, Berthier et al. 2012). The largest single area loss that was not due to sudden removal of an ice shelf buttress was from the large Fuchs Ice Piedmont on Adelaide Island $\left(60 \mathrm{~km}^{2}\right)$.

Although quantifying absolute area of ice loss is important, calculating relative changes is also essential when comparing the behaviour of glaciers with such diverse areas (compare Fig. 6a \& b). Glaciers, such as Fleming Glacier, may have shown a large absolute change but this area is a relatively small percentage of its basin size. Similarly, Fuchs Ice Piedmont has a long ice front which has contributed to the large overall ice loss, but the basin size is also large, resulting in a smaller relative change. Trooz Glacier is one of only two glaciers that have advanced by $>1 \mathrm{~km}^{2}$, and yet it changed by $<1 \%$ of its basin size.

Table III shows a significant correlation between glacier basin area and absolute area loss (Spearman's rank $\left.r_{s}=0.51\right)$. Although there is a weak correlation between glacier area and relative loss $\left(r_{s}=-0.26\right)$, it is significant and negative, implying that smaller basins show larger relative ice loss. When other glacier attributes are correlated against absolute area changes, length and outlet width show significant positive correlations (i.e. the longer glaciers and those with wide fronts have shown large area losses), and mean slope angles show a negative

Table III. Spearman's rank $\left(r_{s}\right)$ correlations between glacier attribute and total change (both absolute change and change relative to basin size as \%).

\begin{tabular}{lcccccc}
\hline Area loss & Glacier area & Length & Mean elevation & Mean slope & Outlet width & Degree of convergence \\
\hline Absolute $\left(\mathrm{km}^{2}\right)$ & $.51^{*}$ & $.42^{*}$ & -.03 & $-.47^{*}$ & $.56^{*}$ & .02 \\
Relative $(\%)$ & $-.26^{*}$ & $-.32^{*}$ & $-.44^{*}$ & .05 & $.09^{*}$ & $.31^{*}$ \\
\hline
\end{tabular}


a

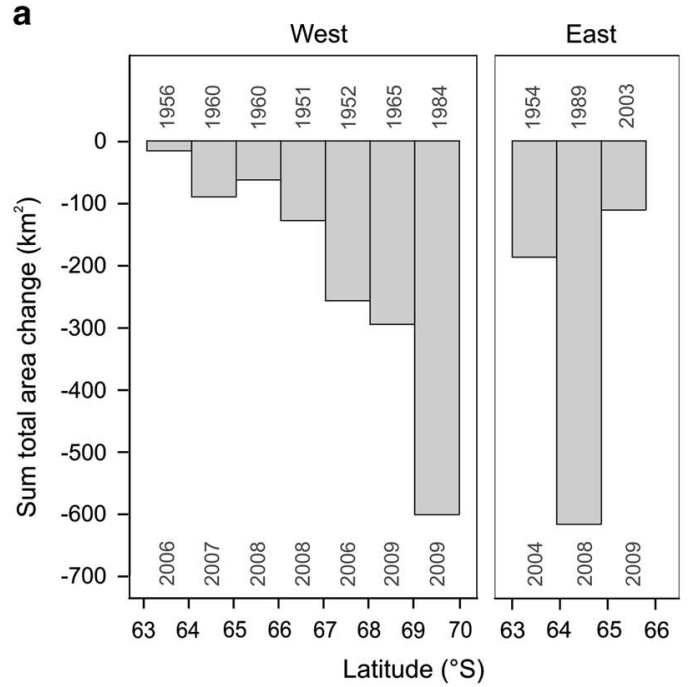

b

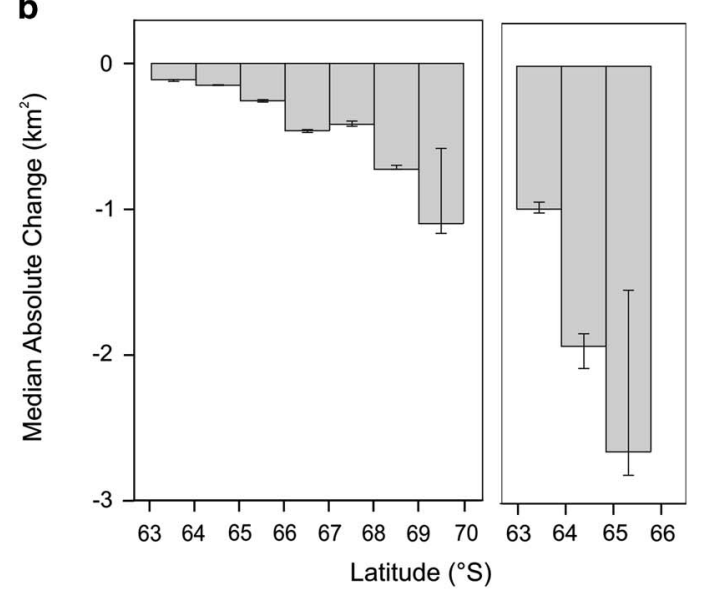

C

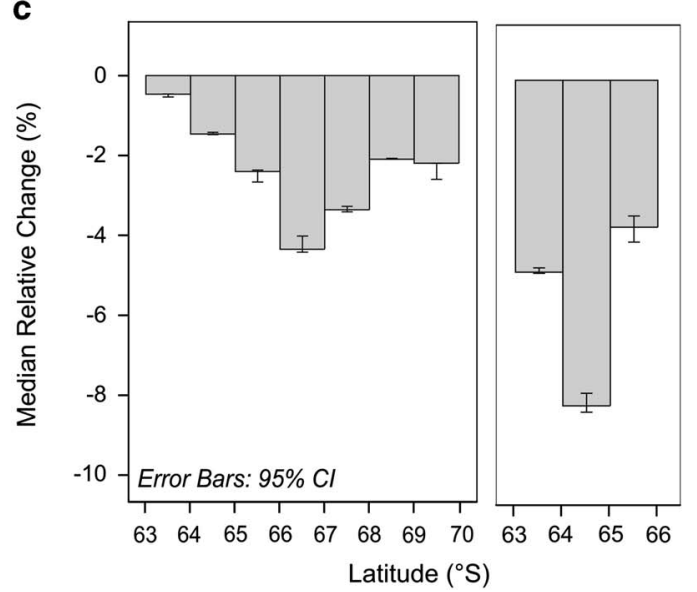

Fig. 7. a. Sum total area change of all glaciers combined (mean years, weighted by basin size, of the first and last recorded positions are shown along the upper and lower x-axis, respectively), b. median absolute change and c. relative change at each degree latitude. b. and c. show median values to account for the wide range in basin sizes and data are weighted according to the number of years between the first and last dates. correlation (i.e. the lower the mean slope angle the larger the area loss). When non-scalar variables, such as Class, Form and Front, are included in the analysis against total loss, floating glaciers show a significantly larger mean absolute change than other frontal types. However, there is no correlation between frontal type and relative change. Some of these variables are co-dependent thus conclusions regarding the primary influence on area change cannot be drawn without a multivariate statistical approach.

Regional total area changes show that on the west coast, there is a substantially increasing ice loss from north to south (Fig. 7a). The east coast glaciers have a large overall loss between $64^{\circ} \mathrm{S}-65^{\circ} \mathrm{S}$ (in the region of Larsen A and Prince Gustav ice shelves), although it must be noted that because the earliest and latest dates differ the overall area loss between $65^{\circ} \mathrm{S}-66^{\circ} \mathrm{S}$ is only recorded since the Larsen B Ice Shelf collapsed in 2002. The mean first date (weighted by area) for the Larsen B tributary glaciers is 2003; positions were recorded for the Hektoria, Jorum and Crane glaciers in 2002, but records for the Mapple, Melville and Pequod glaciers are not available until 2005 when a further section of the ice shelf collapsed. A north to south gradient in increasing absolute area loss per glacier (Fig. 7b) also indicates that there is a strong regional difference in controls on mass loss. Relative changes (Fig. 7c) in the west do not appear to increase south of $67^{\circ}$ but this is probably due to the lack of small glaciers with associated large relative changes. The glaciers in the east show considerably larger mean relative changes at each of the three latitudes than those in the west, which could be explained by the medium-sized glaciers feeding the Larsen A and B ice shelves that retreated rapidly following the demise of the ice shelves. The east and west sides of the AP exhibit markedly different spatial patterns of ice loss, highly influenced by the location of ice shelves.

The overall ice loss from earliest to latest positions indicates the amount of change over the longest available time frame, but the earliest dates are not consistent. A way of identifying temporal trends is by assigning every ice-front position to a 5-year interval and measuring all glacier areas relative to the glacier area in the time interval 2000-04, which is the one time interval for which we have data for all glaciers. The temporal trend in area changes is summarized in Fig. 8a. To contend with the varying sample sizes between each interval the data is up-scaled on a spatial basis, by calculating areas from glaciers with data to the rest of the sample, to give an estimation of total area. The number of glaciers with data within each interval is shown in Fig. 8b (data for intervals with $<50$ glaciers were omitted since reliability from up-scaling would be significantly reduced). These results are based on glaciers with a first date prior to 1995 (816 of 860 glaciers), since a spurious increase in the overall area occurs when first values were added for glaciers post-ice 


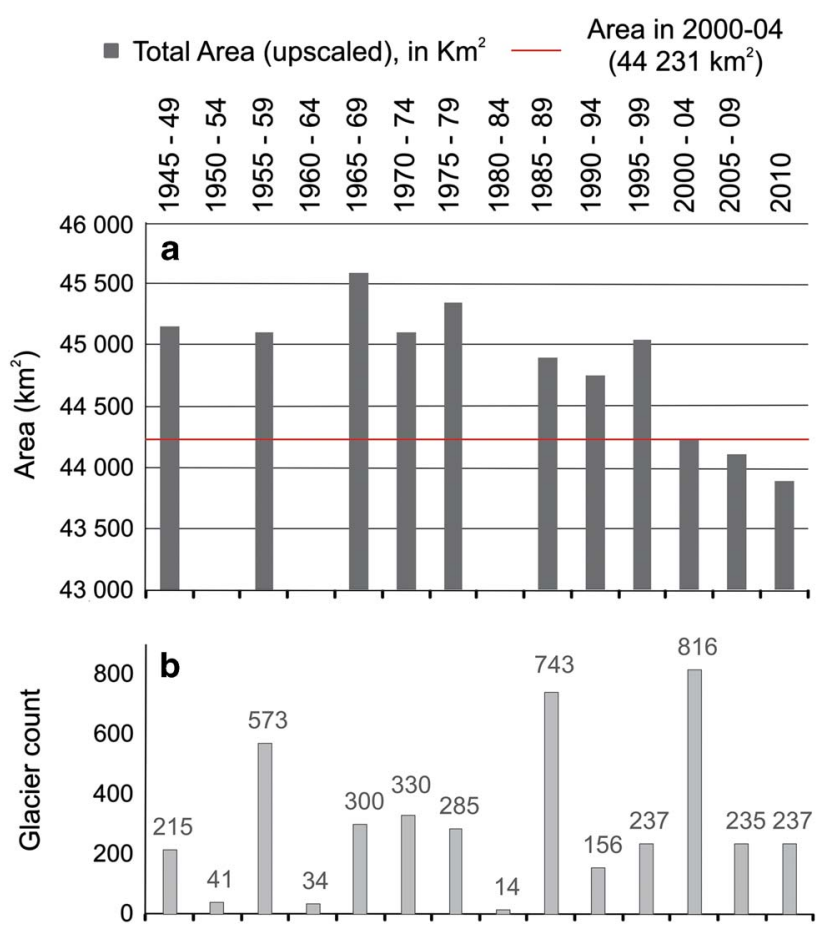

Fig. 8. a. Up-scaled areas for all 816 glaciers with first dates prior to 1995 . b. Number of glaciers with ice-front positions in each interval.

shelf collapse. Furthermore, to reduce misinterpretation of temporal trends from such a large sample size, the results can be assessed against a subset of glaciers that have positional records at as many adjacent intervals as possible (Fig. 9a). The total number of glaciers that have nine or more records since $1945(n=36)$ were selected and intervals containing $>20$ records were up-scaled.

The overall trend shown in both Figs $8 \mathrm{a} \&$ 9a is of broadly consistent retreat, although differences prior to 1980 mean it is difficult to draw conclusions on any early trends. The main observation from this period is that the area is greater in all pre-1980 intervals than in any interval since. There appears to be a steady decrease in area from the late 1970s through to 2010 for both datasets, with the exception being a notable advance in the late 1990s in the complete dataset. The difference between the two datasets for this interval could be due to one of two reasons: i) the small sample of 36 glaciers does not capture all temporal signals since they are not evenly distributed throughout the AP, or ii) the up-scaling method for the complete dataset is less robust during the 1990s than intervals on either side since fewer glaciers have data at this time. However, the 237 (30\%) glaciers with data in 1995-99 are widely distributed throughout the AP and represent all glacier types, thus the area increase is considered to represent a true signal at this time. There is no clear difference in rate of retreat between other adjacent intervals.

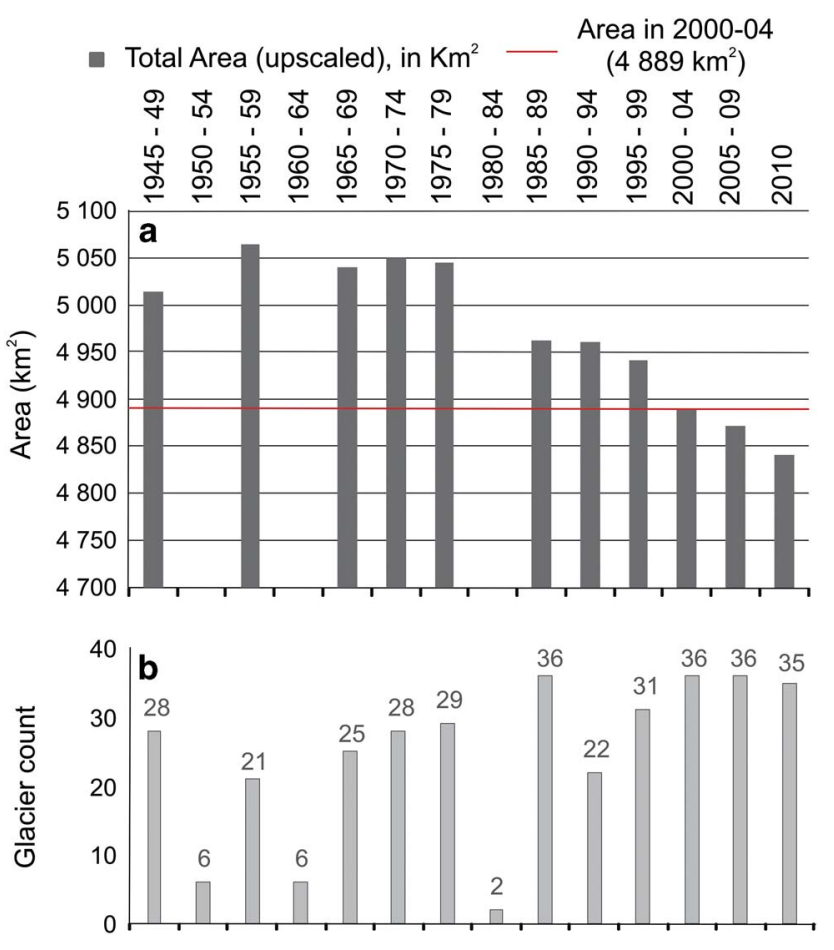

Fig. 9. a. Up-scaled areas for all glaciers with frontal records in nine or more time intervals (36 glaciers). b. Number of glaciers with ice-front positions in each interval.

The results presented above represent a summary of the changes recorded by the dataset. Further analyses of the spatio-temporal patterns of rates of change, the specific causes of regional differences and the influence of glacier character on temporal patterns of change will be undertaken.

\section{Conclusion}

Recent modelling (Hock et al. 2009, Barrand et al. 2013b) has demonstrated that there is a need for a complete inventory of glacier outlines for glacier research in the AP where, not only is the climate distinctly warmer and warming more quickly than elsewhere on the ice sheet, but the smaller glaciers respond more quickly to these higher temperatures. Mapping glaciers in the region poses challenges but, using GIS tools, a high-resolution DEM and criteria set out in GLIMS as a guide, we have compiled outlines of 1590 glacier drainage basins on the mainland and surrounding islands between $63^{\circ} \mathrm{S}-70^{\circ} \mathrm{S}$, together with relevant attributes. In addition, ice-front positions from archival records dating back to 1945 have been combined with the outlines resulting in a total of 4343 glacier basin area measurements. The preliminary analysis of the glacier changes shows that $90.5 \%$ of the 860 marine-terminating glaciers have reduced in area since the earliest records. There is a clear difference in glacier behaviour between the east and west sides of the 
$\mathrm{AP}$, with those in the north-east showing greater relative change than those at the same latitude on the west side. There is a north-south gradient of increasing area loss along the west coast and greatest ice loss is strongly associated with the location of recently-collapsed ice shelves. The largest areas have been lost from large glaciers flowing into Wordie Bay in the south-west, and those flowing into the Larsen A and B embayments. These results correspond with other studies that showed mass loss due to glacier acceleration and surface lowering following ice-shelf collapse. Although such a large dataset with a wide range of glacier sizes and types contains significant variability in temporal trends, by up-scaling the area changes we have shown there was a largely uniform retreat from the late 1970s to 2010, punctuated by an advance in the late 1990s. This study has demonstrated the use of the glacier drainage basin dataset to further our understanding of glacier change in the region and can offer a resource for continued glacier monitoring.

\section{Acknowledgements}

This work was largely supported through an AXA (global investment and insurance group) Research Fund Fellowship. We are grateful to Christian Kienholz at the University of Fairbanks for providing a test version of his GIS algorithm to produce the initial glacier centreline data. We would like to thank A. Hughes, E. Steig and the anonymous reviewer for their very helpful and constructive comments to improve the manuscript.

\section{References}

Barrand, N.E., Machguth, H. \& Hagen, J.O. 2013a. Observing changes in near-polar glaciers in the Northern and Southern Hemispheres. Eos, Transactions American Geophysical Union, 94, 208. Barrand, N.E., Hindmarsh, R.C.A., Arthern, R.J., Williams, C.R., Mouginot, J., Scheuchl, B., Rignot, E., Ligtenberg, S.R.M., van den Broeke, M.R., Edwards, T.L., Cook, A.J. \& Simonsen, S.B. 2013b. Computing the volume response of the Antarctic Peninsula ice sheet to warming scenarios to 2200. Journal of Glaciology, 59, 397-409.

Berthier, E., Scambos, T.A. \& Shuman, C.A. 2012. Mass loss of Larsen B tributary glaciers (Antarctic Peninsula) unabated since 2002. Geophysical Research Letters, 39, 10.1029/2012GL051755.

Bindschadler, R., ChOI, H. \& Wichlacz, A. et al. 2011. Getting around Antarctica: new high-resolution mappings of the grounded and freelyfloating boundaries of the Antarctic ice sheet created for the International Polar Year. Cryosphere, 5, 569-588.

Bindschadler, R., Vornberger, P., Fleming, A., Fox, A., Mullins, J., Binnie, D., Paulsen, S.J., Granneman, B. \& Gorodetzky, D. 2008. The Landsat Image Mosaic of Antarctica. Remote Sensing of Environment, 112, 4214-4226.

Bliss, A., Hock, R. \& Cogley, J.G. 2013. A new inventory of mountain glaciers and ice caps for the Antarctic Periphery. Annals of Glaciology, 54, 191-199.

Bolch, T., Menounos, B. \& Wheate, R. 2010. Landsat-based inventory of glaciers in western Canada, 1985-2005. Remote Sensing of Environment, 114, 127-137.
Braun, M., Simoes, J.C., Vogt, S., Bremer, U.F., Blindow, N., Pfender, M., Saurer, H., Aquino, F.E. \& Ferron, F.A. 2001. An improved topographic database for King George Island: compilation, application and outlook. Antarctic Science, 13, 41-52.

Chen, J.L., Wilson, C.R., Blankenship, D. \& Tapley, B.D. 2009. Accelerated Antarctic ice loss from satellite gravity measurements. Nature Geoscience, 2, 859-862.

Cook, A.J., Fox, A.J., Vaughan, D.G. \& Ferrigno, J.G. 2005. Retreating glacier fronts on the Antarctic Peninsula over the past half-century. Science, 308, 541-544.

CoOK, A.J., Murray, T., Luckman, A., Vaughan, D.G. \& Barrand, N.E. 2012. A new 100-m Digital Elevation Model of the Antarctic Peninsula derived from ASTER Global DEM: methods and accuracy assessment. Earth System Science Data, 4, 10.5194/essd-4-129-2012.

Davies, B.J., Carrivick, J.L., Glasser, N.F., Hambrey, M.J. \& SMELLIE, J.L. 2012. Variable glacier response to atmospheric warming, northern Antarctic Peninsula, 1988-2009. Cryosphere, 6, 1031-1048.

Ferrigno, J.G., Cook, A.J., Foley, K.M., Williams, R.S., Swithinbank, C., Fox, A.J., Thomson, J.W. \& Sievers, J. 2006. Coastal-change and glaciological map of the Trinity Peninsula area and South Shetland Islands, Antarctica: 1843-2001. US Geological Survey Geologic Investigations Series Map I-2600-A, 1 map sheet, 32 pp.

Ferrigno, J.G., Cook, A.J., Mathie, A.M., Williams, R.S., Swithinbank, C., Foley, K.M., Fox, A.J., Thomson, J.W. \& Sievers, J. 2008. Coastal-change and glaciological map of the Larsen Ice Shelf area, Antarctica: 1940-2005. US Geological Survey Geologic Investigations Series Map I-2600-B, 1 map sheet, 28 pp.

Ferrigno, J.G., Cook, A.J., Mathie, A.M., Williams, R.S., Swithinbank, C., Foley, K.M., Fox, A.J., Thomson, J.W. \& Sievers, J. 2009. Coastal-change and glaciological map of the Palmer Land area, Antarctica: 1947-2009. US Geological Survey Geologic Investigations Series Map I-2600-C, 1 map sheet, 28 pp.

Hock, R., De Woul, M., Radic, V. \& Dyurgerov, M. 2009. Mountain glaciers and ice caps around Antarctica make a large sea-level rise contribution. Geophysical Research Letters, 36, 10.1029/2008GL037020.

Ivins, E.R., Watkins, M.M., Yuan, D.N., Dietrich, R., CASAsSa, G. \& RulKe, A. 2011. On-land ice loss and glacial isostatic adjustment at the Drake Passage: 2003-2009. Journal of Geophysical Research Solid Earth, 116, 10.1029/2010JB007607.

Kienholz, C., Rich, J.L., Arendt, A.A. \& Hock, R. 2014. A new method for deriving glacier centerlines applied to glaciers in Alaska and northwest Canada. The Cryosphere, 8, 10.5194/tc-8-503-2014.

Kunz, M., King, M.A., Mills, J.P., Miller, P.E., Fox, A.J., Vaughan, D.G. \& MARSH, S.H. 2012. Multi-decadal glacier surface lowering in the Antarctic Peninsula. Geophysical Research Letters, 39, 10.1029/ 2012GL052823.

Meredith, M.P. \& King, J.C. 2005. Rapid climate change in the ocean west of the Antarctic Peninsula during the second half of the 20th century. Geophysical Research Letters, 32, 10.1029/2005GL024042.

Mulvaney, R., Abram, N.J., Hindmarsh, R.C.A., Arrowsmith, C., Fleet, L., Triest, J., Sime, L.C., Alemany, O. \& Foord, S. 2012. Recent Antarctic Peninsula warming relative to Holocene climate and ice-shelf history. Nature, 489, 141-204.

Paul, F., KaAb, A., Maisch, M., Kellenberger, T. \& Haeberli, W. 2002. The new remote-sensing-derived Swiss glacier inventory: I. Methods. Annals of Glaciology, 34, 355-361.

Pritchard, H.D. \& Vaughan, D.G. 2007. Widespread acceleration of tidewater glaciers on the Antarctic Peninsula. Journal of Geophysical Research, 112, 10.1029/2006JF000597.

Pritchard, H.D., Arthern, R.J., Vaughan, D.G. \& Edwards, L.A. 2009. Extensive dynamic thinning on the margins of the Greenland and Antarctic ice sheets. Nature, 461, 971-975.

Rabassa, J., Skvarca, P., Bertani, L. \& Mazzoni, E. 1982. Glacier inventory of James Ross and Vega Islands, Antarctic Peninsula. Annals of Glaciology, 3, 260-264. 
Rau, F., Kargel, J.S. \& Raup, B.H. 2006. The GLIMS glacier inventory of the Antarctic Peninsula. The Earth Observer, 18, 9-11.

Rau, F., Mauz, F., De Angelis, H., Jana, R., Neto, J.A., Skvarca, P., Vogt, S., Saurer, H. \& Gossmann, H. 2004. Variations of glacier frontal positions on the northern Antarctic Peninsula. Annals of Glaciology, 39, 525-530.

Rau, F., Mauz, F., Vogt, S., Khalsa, S.J.S. \& Raup, B. 2005. Illustrated GLIMS glacier classification manual. Version 1.0. Freiburg: Institut für Physische Geographie, $36 \mathrm{pp}$.

Rignot, E., Casassa, G., Gogineni, S., Kanagaratnam, P., Krabill, W., Pritchard, H., Rivera, A., Thomas, R. \& Vaughan, D. 2005. Recent ice loss from the Fleming and other glaciers, Wordie Bay, West Antarctic Peninsula. Geophysical Research Letters, 32, 10.1029/2004GL021947.

Rignot, E., Mouginot, J. \& Scheuchl, B. 2011. Ice flow of the Antarctic Ice Sheet. Science, 333, 1427-1430.

Rott, H., Muller, F., Nagler, T. \& Floricioiu, D. 2011. The imbalance of glaciers after disintegration of Larsen-B ice shelf, Antarctic Peninsula. Cryosphere, 5, 125-134.

Scambos, T.A., Bohlander, J.A., Shuman, C.A. \& Skvarca, P. 2004. Glacier acceleration and thinning after ice shelf collapse in the Larsen B embayment, Antarctica. Geophysical Research Letters, 31, 10.1029/2004GL020670.

Shuman, C.A., Berthier, E. \& Scambos, T.A. 2011. 2001-2009 elevation and mass losses in the Larsen A and B embayments, Antarctic Peninsula. Journal of Glaciology, 57, 737-754.
Smith, R.C. \& Stammerjohn, S.E. 2001. Variations of surface air temperature and sea-ice extent in the western Antarctic Peninsula region. Annals of Glaciology, 33, 493-500.

Steig, E.J., Schneider, D.P., Rutherford, S.D., Mann, M.E., Comiso, J.C. \& Shindell, D.T. 2009. Warming of the Antarctic ice-sheet surface since the 1957 International Geophysical Year. Nature, 457, 459-464. Corrigendum: Nature, 460, 766.

Thomas, E.R., Marshall, G.J. \& McConnell, J.R. 2008. A doubling in snow accumulation in the western Antarctic Peninsula since 1850. Geophysical Research Letters, 35, 10.1029/2007GL032529.

Turner, J., Colwell, S.R., Marshall, G.J., Lachlan-Cope, T.A., Carleton, A.M., Jones, P.D., Lagun, V., Reid, P.A. \& Iagovinina, S. 2005. Antarctic climate change during the last 50 years. International Journal of Climatology, 25, 279-294.

Vaughan, D.G., Marshall, G.J., Connolley, W.M., Parkinson, C., Mulvaney, R., Hodgson, D.A., King, J.C., Pudsey, C.J. \& Turner, J. 2003. Recent rapid regional climate warming on the Antarctic Peninsula. Climatic Change, 60, 243-274.

Wendt, J., Rivera, A., Wendt, A., Bown, F., Zamora, R., Casassa, G. \& Bravo, C. 2010. Recent ice-surface-elevation changes of Fleming Glacier in response to the removal of the Wordie Ice Shelf, Antarctic Peninsula. Annals of Glaciology, 51, 97-102.

Williams, R.S., Ferrigno, J.G., Swithinbank, C., Lucchitta, B.K. \& SeEkins, B.A. 1995. Coastal-change and glaciological maps of Antarctica. Annals of Glaciology, 21, 284-290. 